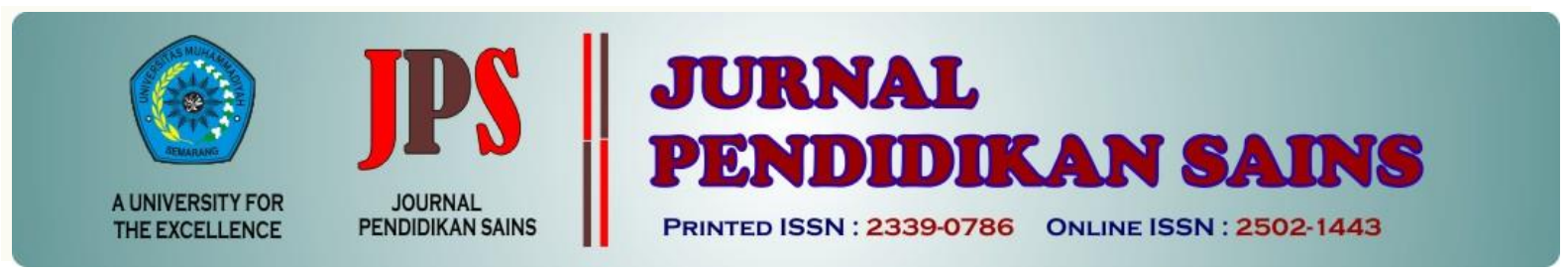

http://jurnal.unimus.ac.id/index.php/JPKIMIA

\title{
PROGRAM SCIENCES KIDS COMMUNITY BERBASIS GROUP INVESTIGATION UNTUK MENINGKATKAN KEMAMPUAN PEMECAHAN MASALAH SISWA MADRASAH IBTIDAIYAH
}

\author{
Oleh: \\ Anggun Zuhaida \\ IAIN salatiga
}

\begin{tabular}{ll}
\hline \multicolumn{2}{l}{ Article history } \\
\hline Submission & $: 2018-07-27$ \\
Revised & $: 2018-08-06$ \\
Accepted & $: 2018-09-12$
\end{tabular}

Keyword:

Group Investigation, Problem Solving Skills, Science Kids Community

\begin{abstract}
The Science Kids Community program is implemented using Group Investigation (GI) model which is part of cooperative learning. This study aims to explain the implementation of the Science Kids Community program based on GI and also to determine the results of improving problem-solving skills in students. This research is focused on the implementation of science learning in Madrasah Ibtidaiyah (MI) students. The method used in this research is descriptive with qualitative approach. Instruments in this study, using questionnaire, problem solving test, and interview. Subjects in this study were the students of $5^{\text {th }}$ class MI NU Miftahul Ulum 2 Kudus. The implementation of the Science Kids Community program with the GI model provides wider opportunities and authority for students to jointly solve problems of science learning. The results of problem solving skills, focused on 2 groups of students, namely students with high motivation category (category A) and students with moderate motivation category (category B). Obtained results, in Category A students: the maximum at the stage identify the problem, define the purpose, and execute the strategy. While the category B students, the new maximum at the stage of implementing the strategy. This can make the input for teachers, to more often implement group-based learning model / community to be able to improve students problem solving skills
\end{abstract}

\section{Pendahuluan}

Perkembangan ilmu pengetahuan dan teknologi dewasa ini terus berkembang pesat dan menuntut diimbangi dengan Sumber Daya Manusisa (SDM) yang handal. Maka dari itu kebutuhan SDM tersebut tidak dapat ditawartawar lagi. Berbagai tugas dan pekerjaan membutuhkan pengetahuan dan keterampilan yang memadai bagi setiap orang. Upaya meningkatkan kualitas pendidikan salah satu kuncinya adalah meningkatkan kualitas para guru. Pengetahuan dan keterampilan guru perlu mendapat perhatian, sehingga secara bertahap apa yang disebut profesionalisme guru benarbenar menjadi kenyataan.

Guru yang profesional bukan hanya sekedar alat transmisi ilmu tetapi juga harus

*Corresponding Author:

Nama : Anggun Zuhaida

Lembaga : IAIN Salatiga

Email : anggunzuh@iainsalatiga.ac.id 
bisa mendidik dan menciptakan suatu proses pembelajaran yang menyenangkan dan mudah dimengerti oleh siswa. Belajar harus dilakukan oleh siswa secara aktif baik individual maupun kelompok dengan cara memecahkan masalah. Keberhasilan proses pembelajaran di sekolah dapat ditentukan dengan mengukur ketercapaian tujuan pendidikan yang tercantum dalam kurikulum yang mencerminkan penguasaan materi pelajaran yang diperoleh siswa dalam suatu program pendidikan. Maka diperlukan proses belajar efektif agar dapat membantu siswa untuk meningkatkan kemampuan yang diharapkan sesuai dengan tujuan instruksional yang ingin dicapai (Destalia, 2014: 213-214).

Masalah umum dalam pembelajaran sains yang terjadi pada Sekolah Dasar/Madrasah Ibtidaiyah (SD/MI)adalah siswa merasakan kegiatan pembelajaran sains di sekolah masih menekankan penguasaan konsep dan target setumpuk materi. Target kurikulum yang terkesan dipaksakan kepada siswa tentunya akan membuat siswa frustasi. Dampak kronisnya adalah timbulnya kebencian siswa terhadap mata pelajaran sains. Kebencian ini akan bermuara pada nilai akademis yang buruk dan justifikasi bodoh akan melekat padanya. Bahkan, banyak sekali lembaga pendidikan yang masih mendewakan drilling soal yang tentunya aspek kognisi saja yang tajam. Padahal ada aspek psikomotorik dan afektif yang perlu juga diperhatikan.

Pembelajaran hendaknya dimulai dengan pengenalan masalah atau dengan mengajukan masalah-masalah yang lebih nyata dengan mengaitkan pembelajaran pada kehidupan sehari-hari siswa dan kemudian secara bertahap siswa dapat dibimbing menguasai konsep dengan melibatkan siswa secara langsung untuk aktif selama proses pembelajaran. Indikator untuk mencapai pembelajaran yang berkualitas adalah perilaku guru dalam pembelajaran, perilaku dan dampak belajar siswa, iklim pembelajaran, materi pembelajaran yang berkualitas dan kualitas media pembelajaran. Faktor penting dalam merangsang pemikiran kritis dari peserta didik terhadap materi yang dipelajari adalah pemilihan metode dan model pembelajaran (Sary, 2015: 2).

Perlunya mengurai benang kusut untuk menemukan titik pangkal permasalahan perlu dilakukan. Aktivitas pembelajaran sains yang berbasis hands on dan minds on perlu menjadi perhatian lebih dalam dunia pembelajaran sains.
Bermain dalam kegembiraan adalah naluri alamiah seorang anak. Pembelajaran sains tidak perlu mengikis kesempatan bermain mereka.

Berdasarkan hal tersebut maka diperlukan suatu kegiatan belajar melalui kebersamaan dengan menggunakan landasan learning to live together. Kegiatan belajar tersebut dilaksanakan melalui program Science Kids Community yang dilaksanakan dengan menggunakan suatu model pembelajaran Group Investigation (GI) yang merupakan bagian dari Cooperative Learning. Pemilihan model pembelajaran yang tepat sangatlah penting agar tujuan pembelajaran dapat tercapai. Meskipun tujuan pembelajaran dirumuskan dengan baik, materi yang dipilih sudah tepat, jika model pembelajaran yang dipergunakan kurang memadai mungkin tujuan yang diharapkan tidak tercapai dengan baik. Jadi, model pembelajaran merupakan salah satu komponen pembelajaran yang penting dan sangat menentukan dalam keberhasilan proses pembelajaran (Hartoto, 2016: 132-133).

Model pembelajaran GI merupakan model pembelajaran kooperatif yang mengharuskan siswa untuk aktif dan berpartisipasi dalam proses pembelajaran dengan cara menggali/mencari informasi/materi yang akan dipelajari secara mandiri dengan bahan-bahan yang tersedia (Medyasari dkk dalam Wicaksono dkk, 2017: 2). Pemilihan model GI dirasa cocok jika diterapkan dalam program pembelajaran tersebut karena model pembelajaran kooperatif tipe GI dapat memberikan kesempatan bagi siswa untuk berpartisipasi dalam memecahkan masalah dengan benda konkret yang dikaji antar individu dalam suatu kelompok. Selain itu model GI lebih menekankan pada proses pencarian pengetahuan dari pada transfer pengetahuan (Arisinta dkk, 2017: 733).

Program Science Kids Community mengajak siswa untuk belajar melalui aktivitas bersama, saling diskusi, menjadi pendengar dan pembicara yang baik. Aktivitas melalui komunitas mampu meredam keegoisan seorang anak. Science Kids Community menekankan pentingnya belajar melalui kebersamaan menjadi landasan komunitas. Anak-anak selalu memunculkan keingintahuan dan membutuhkan lingkungan yang mendukung mereka untuk mengembangkan keingintahuan mereka terhadap sains. Science Kids Community menyadari akan pentingnya kemampuan pemecahan masalah yang dikemas melalui kegiatan eksperimen dan eksplorasi sains. 
Penelitian ini nantinya akan menjelaskan bagaimana pelaksanaan dan hasil dari program Science Kids Community berbasis Group Investigation untuk meningkatkan kemampuan pemecahan masalah bagi siswa MI di Kabupaten Kudus.

\section{Metode}

Penelitian ini merupakan bentuk penelitian deskriptif, karena bertujuan untuk membuat deskripsi secara sistematis, faktual dan akurat mengenai fakta-fakta, dan sifat-sifat populasi (Suryana, 2010). Pendekatan yang digunakan dalam penelitian ini adalah menggunakan pendekatan kualitatif.

Metode kualitatif digunakan untuk deskripsi hasil validasi ahli, hasil angket, wawancara dan observasi tentang program Science Kids Community berbasis GI untuk meningkatkan kemampaun pemecahan masalah siswa. Desain penelitian dimulai dari perencanaan, pengembangan instrumen, pengumpulan data, analisis data, dan uraian temuan. Pada tahap perencanaan, peneliti mengidentifikasi informasi yang dibutuhkan dan darimana informasi tersebut akan diperoleh.

Langkah pembuatan instrumen dilakukan dengan: 1) menentukan subjek penelitian: subjek penelitian ini menggunakan sampel penelitian. Sampel dalam penelitian ini diambil dengan teknik Purposive Sampling karena disesuaikan dengan tujuan penelitian sehingga diharapkan dapat menjawab permasalahan penelitian. Sampel dalam penelitian ini yaitu Siswa Kelas V MI NU Miftahul Ulum 2 Honggosoco Jekulo Kudus pada Semester genap Tahun Ajaran 2016/2017, 2) menentukan jenis instrumen yang digunakan yaitu berupa: angket, lembar observasi, dan wawancara. Penyusunan instrumen angket, tes, dan wawancara dilakukan dengan terlebih dahulu melakukan validasi isi dan konstruk oleh ahli. Instrumen angket digunakan pada awal penelitian, digunakan untuk mengukur motivasi belajar siswa yang dibagi menjadi tiga tingkatan, yaitu: tinggi sedang, dan rendah. Selanjutnya pada pelaksanaan, siswa diberikan tes untuk mengetahui kemampuan pemecahan masalah. Instrumen wawancara digunakan untuk menguatkan dan mengkonfirmasi hasil tes yang telah dilakukan.

Analisis data kualitatif digunakan berdasarkan hasil dari instrumen angket, lembar observasi, dan wawancara. Hasil yang diperoleh selanjutnya dianalisis secara deskriptif. Dari data-data yang diperoleh, direduksi kemudian dibuat polanya sehingga diperoleh gambaran peningkatan kemampuan pemecahan masalah siswa menggunakan model Miles dan Huberman (Ghony dan Almanshur, 2012).

\section{Hasil dan Pembahasan \\ Science Kids Community Berbasis Group Investigation}

Science Kids Community merupakan suatu program yang dilaksanakan pada pembelajaran IPA di MI yang dikembangkan dengan pendekatan Group Investigation (GI). GI mulanya dirancang oleh Herbert Thelen yang selanjutnya dikembangkan oleh Sharan dkk di Tel Aviv University. GI merupakan bagian dari pendekatan cooperative learning yang paling sulit diimplementasikan. Berbeda dengan STAD dan jigsaw, GI melibatkan siswa dalam merencanakan topik-topik yang akan dipelajari dan bagaimana cara menjalankan investigasinya. Hal ini membutuhkan norma dan struktur kelas yang lebih canggih dibanding pendekatan yang lebih teacher-centered (Arends, 2008: 13-14).

Guru yang menggunakan pendekatan GI biasanya membagi kelasnya menjadi kelompokkelompok heterogen yang masing-masing beranggota lima atau enam orang. Akan tetapi, di beberapa kasus, kelompok mungkin dibentuk di seputar minat terhadap topik tertentu. Siswa memilih topik-topik untuk dipelajari, melakukan investigasi mendalam terhadap subtopik yang dipilih, dan kemudian menyiapkan dan mempresentasikan laporan kepada seluruh kelas. Sharan (1984), dkk mendeskripsikan enam langkah pendekatan GI:

1. Pemilihan topik. Siswa memilih subtopik tertentu dalam bidang permasalahan umum tertentu, yang biasanya diterangkan oleh guru. Siswa kemudian diorganisasikan ke dalam kelompok-kelompok kecil berorientasi tugas yang beranggota dua sampai enam orang. Komposisi kelompoknya heterogen baik secara akademis maupun etnis.

2. Cooperative learning. Siswa dan guru merencanakan prosedur, tugas, dan tujuan belajar tertentu sesuai dengan subtopik yang dipilih dalam langkah 1

3. Implementasi. Siswa melaksanakan rencana yang diformulasikan dalam langkah 2. Pembelajaran mestinya melibatkan beragam kegiatan dan keterampilan dan seharusnya mengarahkan siswa ke berbagai macam sumber di dalam 
maupun di luar sekolah. Guru mengikuti dari dekat perkembangan masing-masing kelompk dan menawarkan bantuan bila dibutuhkan.

4. Analisis dan sintesis. Siswa menganalisis dan mengevaluasi informasi yang diperoleh selama langkah 3 dan merencanakan bagaimana informasi itu dapat dirangkum dengan menarik untuk dipertontonkan atau dipresentasikan kepada teman-teman sekelas.

5. Presentasi produk akhir. Beberapa atau semua kelompok di kelas memberikan presentasi menarik tentang topik-topik yang dipelajari untuk membuat satu sama lain saling terlibat dalam pekerjaan temannya dan mencapai perspektif yang lebih luas tentang sebuah topik. Presentasi kelompok dikoordinasikan oleh guru.

6. Evaluasi. Dalam kasus-kasus yang kelompoknya menindaklanjuti aspek-aspek yang berbeda dari topik yang sama, siswa dan guru mengevaluasi kontribusi masingmasing kelompok ke hasil pekerjaan kelas secara keseluruhan. Evaluasi dapat memasukkan asesmen individual atau kelompok, atau kedua-duanya (Arends, 2008: 14-15).

\section{Kemampuan Pemecahan Masalah}

Gagne mengemukakan belajar pemecahan masalah adalah tingkat tertinggi dari hierarki belajar maka harus dikuasai oleh siswa, bahkan tercermin dalam konsep kurikulum berbasis kompetensi. Tuntutan akan kemampuan pemecahan masalah dipertegas secara eksplisit dalam kurikulum tersebut yaitu, sebagai kompetensi dasar yang harus dikembangkan dan diintegrasikan pada sejumlah materi yang sesuai. Dengan demikian, kemampuan pemecahan masalah merupakan komponen penting dalam pembelajaran, sehingga dengan sendirinya siswa mampu dan memiliki kemampuan dasar yang kemudian siswa dapat membuat strategi dalam memecahkan masalah yang lebih efektif (Suherman, 2003: 34).

John Dewey mengemukakan beberapa langkah-langkah memecahkan masalah yang harus dicapai dalam memecahkan masalah adalah sebagai berikut :

1. Mengidenfikasi dan merumuskan masalah.

Pada tahap ini, guru menjelaskan tujuan pembelajaran dan menjelaskan hal-hal yang diperlukan selama pelajaran serta memotivasi peserta didik untuk terlibat pada aktivitas pemecahan masalah dengan contoh situasi masalah dalam kehidupan sehari-hari yang berkaitan dengan materi pembelajaran.

2. Mengemukakan hipotesis. alam tahap ini guru membimbing peserta didik dalam merumuskan hipotesis sesuai dengan masalah yang ada. Pada tahap kedua ini, peserta didik mulai memikirkan dan mengembangkan ide-ide dan mengemukakan langkah-langkah yang harus dilakukan untuk menyelesaikan masalah tersebut.

3. Mengumpulkan data. Dalam tahap ini, peserta didik berdiskusi dengan teman kelompoknya. Guru membimbing peserta didik melakukan kegiatan penemuan dengan mengarahkan peserta didik untuk memperoleh informasi yang diperlukan. Dalam tahap ini peserta didik dituntut untuk mengartikan informasi yang diberikan kedalam bentuk matematika dan merencanakan strategi yang akan dipilih serta melaksanakan rencana yang sudah dipilih dan mempertahankannya. Jika rencana tersebut tidak dapat terlaksana peserta didik dapat memilih cara atau rencana lain.

4. Menguji hipotesis. Dalam tahap ini, beberapa kelompok mempresentasikan hasil diskusi didepan kelas dengan bimbingan dari guru dan kelompok lain menanggapi. Melalui proses pembelajaran ini, peserta didik akan terlibat aktif dan diberikan kesempatan untuk mengemukakan ide-ide serta pendapatnya.

5. Mengambil kesimpulan. menganalisis dan mengevaluasi kegiatan penemuan. Pada fase ini, guru membantu peserta didik melakukan refleksi atau evaluasi serta mengklarifikasi hasil diskusi kemudian guru bersama peserta didik menyimpulkan materi yang telah dipelajari.

Untuk memperoleh kemampuan dalam pemecahan masalah seseorang harus memiliki banyak pengalaman dalam memecahkan berbagai masalah. Siswa dikatakan dapat memecahkan masalah apabila siswa mampu mengidentifikasi serta menyelesaikan soal dengan tahapan-tahapan dalam berbagai bentuk, serta memahami bagaimana ide tematik saling terkait satu sama lain (Nurrahman, 2017: 13).

Program Science Kids Community dalam Pembelajaran IPA di Madrasah Ibtidaiyah (MI) 
Program Science Kids Community dilaksanakan dalam pembelajaran IPA Kelas V semester genap tahun ajaran 2016/2017. Program tersebut dilaksanakan dengan model Group Investigation yang bertujuan untuk meningkatkan kemampuan pemecahan masalah siswa. Rincian pelaksanaan program tersebut dijelaskan pada tabel berikut.

Tabel 1: Program dan Indikator Pelaksanaan Science Kids Community

\begin{tabular}{|c|c|c|c|}
\hline No & $\begin{array}{c}\text { Langkah } \\
\text { Pendekatan } \\
\text { GI }\end{array}$ & Kegiatan Siswa & $\begin{array}{c}\text { Kemampuan } \\
\text { Pemecahan } \\
\text { Masalah }\end{array}$ \\
\hline 1 & $\begin{array}{l}\text { Pemilihan } \\
\text { topik }\end{array}$ & $\begin{array}{l}\text { Siswa memilih } \\
\text { subtopik yang } \\
\text { akan dijadikan } \\
\text { permasalahan } \\
\text { dan selanjutnya } \\
\text { menentukan } \\
\text { kelompok } \\
\text { secara } \\
\text { heterogen }\end{array}$ & $\begin{array}{l}\text { Mengidenti- } \\
\text { fikasi, } \\
\text { merumuskan } \\
\text { masalah }\end{array}$ \\
\hline 2 & $\begin{array}{l}\text { Cooperative } \\
\text { learning }\end{array}$ & $\begin{array}{l}\text { Siswa bersama } \\
\text { dengan guru } \\
\text { merancang } \\
\text { prosedur, tugas, } \\
\text { dan tujuan } \\
\text { pembelajaran } \\
\text { yang } \\
\text { disesuaikan } \\
\text { dengan } \\
\text { subtopik yang } \\
\text { dipilih }\end{array}$ & - \\
\hline 3 & $\begin{array}{l}\text { Imple- } \\
\text { mentasi }\end{array}$ & $\begin{array}{l}\text { Siswa } \\
\text { melaksanakan } \\
\text { rencana yang } \\
\text { telah disusun } \\
\text { sesuai langkah } \\
\text { kedua }\end{array}$ & - \\
\hline 4 & $\begin{array}{l}\text { Analisis } \\
\text { dan } \\
\text { sintesis }\end{array}$ & $\begin{array}{l}\text { Siswa } \\
\text { menganalisis } \\
\text { dan } \\
\text { mengevaluasi } \\
\text { beberapa } \\
\text { informasi yang } \\
\text { telah diperoleh }\end{array}$ & $\begin{array}{l}\text { Mengemu- } \\
\text { kakan hipote- } \\
\text { sis serta } \\
\text { mengumpul- } \\
\text { kan data }\end{array}$ \\
\hline 5 & $\begin{array}{l}\text { Presentasi } \\
\text { produk } \\
\text { akhir }\end{array}$ & $\begin{array}{l}\text { Siswa } \\
\text { mempresentasi } \\
\text { kan hal-hal } \\
\text { yang telah } \\
\text { ditemukannya } \\
\text { kepada } \\
\text { kelompok lain }\end{array}$ & $\begin{array}{l}\text { Menguji } \\
\text { hipotesis }\end{array}$ \\
\hline 6 & Evaluasi & $\begin{array}{l}\text { Siswa dan guru } \\
\text { mengevaluasi }\end{array}$ & $\begin{array}{l}\text { Mengambil } \\
\text { kesimpulan }\end{array}$ \\
\hline
\end{tabular}

yang telah

dilakukan

Pelaksanaan program Science Kids Community dengan model GI memberi kesempatan dan wewenang kepada siswa yang lebih luas untuk secara bersama-sama memecahkan berbagai persoalan tentang pembelajaran sains. Partisipasi dari siswa ini bertujuan untuk mencari solusi permasalahan tentang sains melalui suatu kelompok dengan membuka lebih banyak kesempatan bagi siswa untuk ikut memberikan kontribusi sehingga implementasi kegiatan di dalam kelompok dapat berjalan lebih efektif, efesien, dan berkelanjutan.

\section{Hasil Capaian}

Hasil capaian instrumen angket yang meliputi tentang instrumen motivasi belajar siswa diperoleh hasil sebagai berikut:

Tabel 2: Hasil Capaian Instrumen Angket Motivasi Hasil Belajar

$\begin{array}{cr}\text { Kategori } & \text { Jumlah } \\ \text { Tinggi } & 10 \\ \text { Sedang } & 11 \\ \text { Rendah } & 0\end{array}$

Berdasarkan data Tabel 2 menunjukkan bahwa dari 21 siswa kelas $\mathrm{V}$ di MI NU Miftahul Ulum 2 Kudus, 10 siswa memiliki motivasi belajar tinggi, 11 siswa masuk dalam motivasi belajar sedang. Hasil klasifikasi motivasi belajar siswa tersebut dijadikan acuan bahwa subjek penelitian ini terdiri dari dua kelompok siswa, yaitu siswa dengan motivasi tinggi dan siswa dengan motivasi sedang. Hal tersebut dapat dijadikan acuan untuk mengetahui kemampuan pemecahan masalah siswa dalam menyelesaikan beberapa soal yang diberikan nantinya.

Soal yang digunakan untuk mengukur kemampuan pemecahan masalah yang menghubungkan materi IPA dengan kehidupan sehari-hari. Soal-soal tersebut meliputi beberapa aspek yang diadaptasi dari (Ulya, 2017: 92), yaitu (1) mengidentifikasi masalah, (2) mendefinisikan tujuan, (3) menggali solusi, (4) melaksanakan strategi, (5) mengkaji kembali dan mengevaluasi dampak dari pengaruh. hasil capaian kemampuan pemecahan masalah dapat dilihat dari tabel berikut:

Tabel 3: Hasil Capaian Kemampuan

Pemecahan Masalah

\begin{tabular}{cccc} 
N & Langkah & \multicolumn{2}{c}{ Siswa } \\
o & $\begin{array}{c}\text { Pemecahan } \\
\text { Masalah }\end{array}$ & Kategori A & Kategori B
\end{tabular}




\begin{tabular}{|c|c|c|c|}
\hline \multirow{2}{*}{$\begin{array}{l}\mathbf{N} \\
\mathbf{0}\end{array}$} & \multirow{2}{*}{$\begin{array}{c}\text { Langkah } \\
\text { Pemecahan } \\
\text { Masalah }\end{array}$} & \multicolumn{2}{|c|}{ Siswa } \\
\hline & & Kategori A & Kategori B \\
\hline 1 & $\begin{array}{l}\text { Mengi- } \\
\text { dentifikasi } \\
\text { masalah }\end{array}$ & $\begin{array}{l}\text { - Siswa dapat } \\
\text { menuliskan } \\
\text { informasi } \\
\text { yang } \\
\text { terdapat } \\
\text { dalam } \\
\text { permasala- } \\
\text { han secara } \\
\text { lengkap dan } \\
\text { benar tetapi } \\
\text { belum dapat } \\
\text { menuliskan } \\
\text { informasi } \\
\text { esensial } \\
\text { secara } \\
\text { singkat. } \\
\text { - Siswa sudah } \\
\text { dapat } \\
\text { menggam- } \\
\text { barkan } \\
\text { permasala- } \\
\text { han dalam } \\
\text { bentuk } \\
\text { diagram } \\
\text { alir, namun } \\
\text { belum } \\
\text { runtut } \\
\text { sesuai } \\
\text { dengan } \\
\text { prosesnya }\end{array}$ & $\begin{array}{l}\text { - Siswa dapat } \\
\text { menuliskan } \\
\text { informasi } \\
\text { yang } \\
\text { terdapat } \\
\text { dalam } \\
\text { permasala- } \\
\text { han secara } \\
\text { lengkap, } \\
\text { namun } \\
\text { masih ada } \\
\text { beberapa hal } \\
\text { yang kurang } \\
\text { tepat }\end{array}$ \\
\hline 2 & $\begin{array}{l}\text { Mendefi- } \\
\text { nisikan } \\
\text { tujuan }\end{array}$ & $\begin{array}{l}\text { Siswa dapat } \\
\text { menuliskan } \\
\text { hal } \\
\text { yang } \\
\text { ditanyakan } \\
\text { dengan tepat }\end{array}$ & $\begin{array}{l}\text { Siswa belum } \\
\text { dapat } \\
\text { menuliskan } \\
\text { hal yang } \\
\text { ditanyakan } \\
\text { dengan tepat }\end{array}$ \\
\hline 3 & $\begin{array}{l}\text { Menggali } \\
\text { solusi }\end{array}$ & $\begin{array}{l}\text { Siswa dapat } \\
\text { menuliskan } \\
\text { rencana } \\
\text { pemecahan } \\
\text { masalah } \\
\text { dengan } \\
\text { kalimatnya } \\
\text { sendiri } \\
\text { meskipun } \\
\text { belum } \\
\text { sempurna. }\end{array}$ & $\begin{array}{l}\text { Siswa dapat } \\
\text { menuliskan } \\
\text { rencana } \\
\text { pemecahan } \\
\text { masalah } \\
\text { dengan } \\
\text { kalimatnya } \\
\text { sendiri } \\
\text { meskipun } \\
\text { belum } \\
\text { sempurna dan } \\
\text { runtut. }\end{array}$ \\
\hline 4 & $\begin{array}{l}\text { Melaksa- } \\
\text { nakan } \\
\text { strategi }\end{array}$ & $\begin{array}{l}\text { - Siswa dapat } \\
\text { menyele- } \\
\text { saikan } \\
\text { masalah } \\
\text { dengan } \\
\text { sistematis. }\end{array}$ & $\begin{array}{l}\text { - Siswa dapat } \\
\text { menyelesai- } \\
\text { kan masalah } \\
\text { meskipun } \\
\text { belum } \\
\text { sistematis }\end{array}$ \\
\hline
\end{tabular}

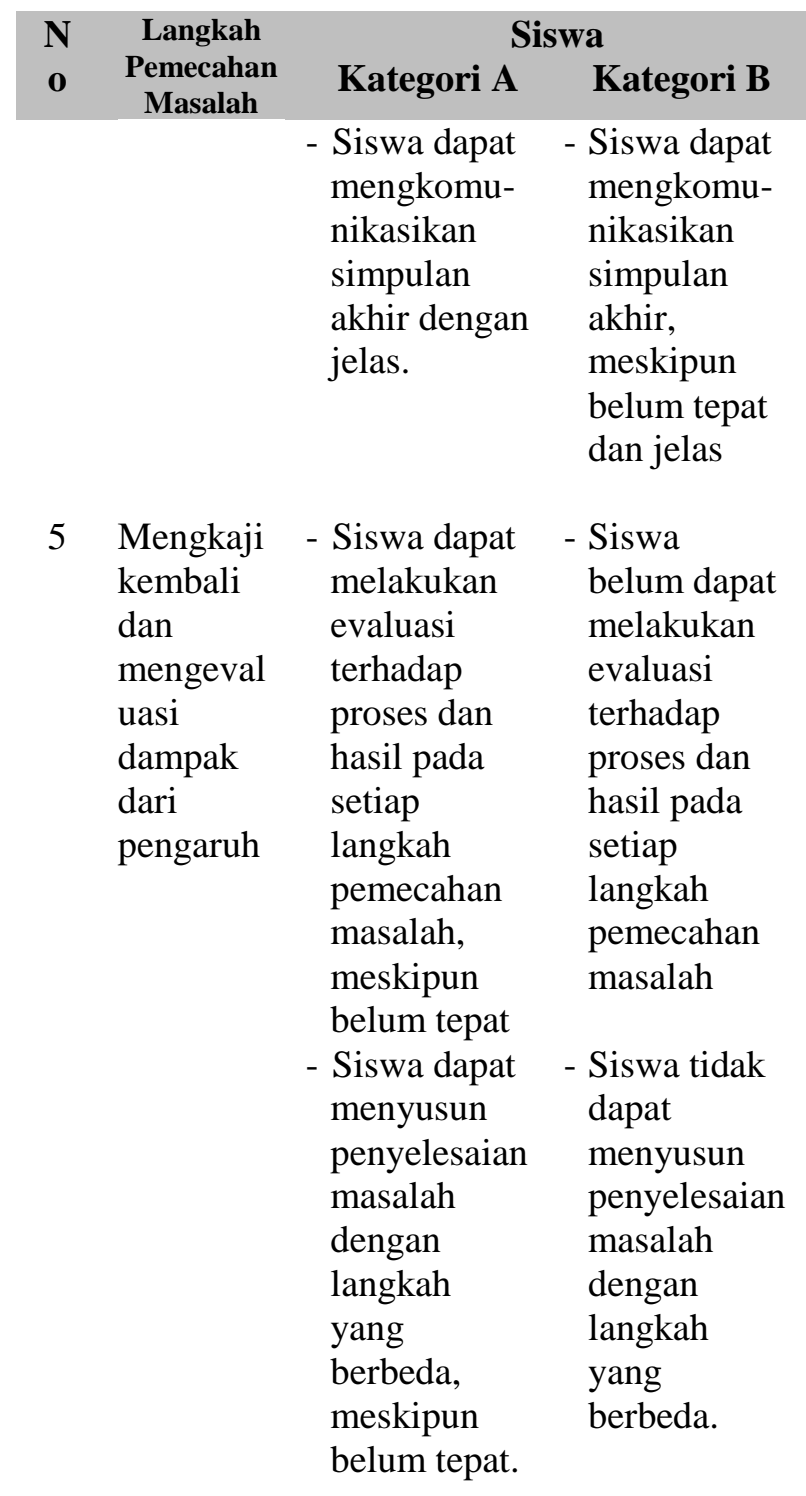

Catatan:

Kategori A: Siswa dengan motivasi tinggi

Kategori B: Siswa dengan motivasi rendah

Berdasarkan tabel 3 diketahui bahwa, siswa kategori A sebagian besar sudah dapat menguasai tahapan-tahapan pemecahan masalah. Pada tahapan mengidentifikasi masalah, mendefinisikan tujuan, dan melaksanakan strategi diketahui bahwa: siswa sudah dapat menyelesaikan dengan baik tahapan-tahapan tersebut. Hal tersebut dikarenakan siswa sudah memahami apa yang harus dilaksanakan dalam pembelajaran dan mempunyai motivasi yang tinggi untuk belajar. Pada tahapan menggali solusi, dan mengkaji kembali evaluasi dampak dari pengaruh diketahui bahwa: siswa belum menunjukkan hasil yang maksimal. Hal tersebut dikarenakan siswa masih hanya fokus pada teori-teori yang diajarkan oleh guru di kelas. Sehingga siswa 
butuh untuk diberi beberapa latihan lagi untuk mengasah kemampuan pemecahan masalahnya.

Siswa kategori B menunjukkan hasil yang maksimal pada tahapan melaksanakan startegi, pada tahapan tersebut diketahui bahwa siswa sudah mampu untuk menyelesaikan dan mengkomunikasikan beberapa permasalahan dengan baik meskipun belum sistematis dan tepat. Sedangkan pada tahapan mengidentifikasi masalah, mendefinisikan tujuan, menggali solusi, dan mengkaji kembali evaluasi dampak dari pengaruh diketahui bahwa: siswa tersebut sebagian besar belum dapat menyelesaikan tahapan tersebut dengan maksimal. Hal tersebut dikarenakan siswa-siswa tersebut membutuhkan beberapa latihan pemecahan masalah yang lebih mendalam. Utamanya dikenalkan pada permasalahan-permasalahan di lingkungan sekitar yang berhubungan dengan sains.

Hasil dari capaian kemampuan pemecahan masalah tersebut diketahui bahwa, pelaksanaan program Science Kids Community berbasis Group Investigation dapat dijadikan suatu alternatif suatu pembelajaran IPA yang menyenangkan bagi siswa tingkatan SD/MI. Melalui program pembelajaran tersebut, selain siswa aktif dalam berdiskusi dan kerja sama dengan kelompok, juga dapat menjadikan siswa semakin mengenal lingkungan sekitar dengan beberapa permasalahannya dan berusaha mencari solusinya.

Kemampuan pemecahan masalah tidak dapat diperoleh secara instan. Hal ini diperlukan latihan secara terus menerus bukan hanya sekedar melalui hafalan, latihan soal rutin, serta proses pembelajaran yang biasa. Guru hendaknya mampu mendesain kegiatan pembelajaran yang disesuaikan dengan tingkatan. Siswa yang sering diberikan beberapa latihan untuk memecahkan masalah, nantinya akan semakin meningkat rasa ingin tahu dan motivasi belajarnya.

\section{Simpulan}

Berdasarkan hasil penelitian yang telah dilakukan, dapat diketahui bahwa: program Science Kids Community berbasis Group Discussion pada pembelajaran IPA di MI NU Miftahul Ulum 2 Kudus dapat meningkatkan kemampuan pemecahan masalah siswa. Didapatkan data, terdapat 10 siswa yang memiliki motivasi belajar tinggi (kategori A) dan 11 siswa dengan motivasi belajar sedang (kategori B). Kedua siswa pada kategori tersebut selanjutnya diberikan suatu tes pemecahan masalah tentang beberapa permasalahan sehari-hari yang berhubungan dengan IPA. Siswa kategori A diketahui, sudah maksimal pada tahapan mengidentifikasi masalah, mendefinisikan tujuan, dan melaksanakan strategi. Sedangkan siswa kategori B, baru maksimal pada tahapan melaksanakan strategi. Hal tersebut dapat dijadikan bagi guru pada khususnya untuk lebih sering memberikan beberapa latihan pemecahan masalah kepada siswa.

\section{Daftar Pustaka}

Arends, R. (2008). Learning to Teach. Translated by Helly Prajitno Soetjipto. Yogyakarta: Pustaka Pelajar

Arisinta, R, dkk. (2017). Pengembangan Group Investigation dengan Permainan "Aku Seorang Detektif" Kelas IV SD Muhammadiyah 1 Malang. Jurnal Pemikiran dan Pengembangan SD . Volume 5, Nomor 2, September 2017

Destalia, L, dkk. (2014). Peningkatan Keterampilan Pemecahan Masalah dan Hasil Belajar melalui Penerapan Pembelajaran Berbasis Masalah (PBM)dengan Metode Eksperimen pada Materi Pencemaran Lingkungan. Jurnal Pancaran. Vol. 3, No. 4, hal 213-224, Nopember 2014

Ghony, M.D. dan Almanshur, F. (2012). Metodologi Penelitian Kualitatif. Yogyakarta: Ar-Ruzz Media.

Hartoto, T. (2016). Model Pembelajaran Kooperatif Tipe Group Investigation (GI) Meningkatkan Aktivitas dan Hasil Belajar Sejarah. Jurnal HISTORIA. Volume 4, Nomor 2, Tahun 2016, ISSN 2337-4713 (e-ISSN 2442-8728).

Nurrahman, A. (2017). Pengembangan LKPD dengan Menggunakan Model Penemuan Terbimbing Terhadap Kemampuan Pemecahan Masalah Matematika Siswa. Tesis. Program Pascasarjana Universitas Lampung.

Suherman, E, dkk. (2003). Strategi Pembelajaran Matematika Kontemporer. Bandung: Jurusan Pendidikan Matematika FPMIPA UPI. 
Sary, R. M, dkk. 2015. Model Problem Based

Learning untuk Menumbuhkan kemampuan Berpikir Kritis Siswa di Sekolah Dasar. Jurnal Malih Peddas Universitas PGRI Semarang. Vol 5, No 2 Desember 2015

Suryana. 2010. Metode Penelitian Metode Praktis Penelitian Kuantitatif dan Kualitatif. Bandung: Universitas Pendidikan Indonesia

Ulya, H. (2017). Profil Kemampuan Pemecahan Masalah Siswa Bermotivasi Belajar Tinggi Berdasarkan Ideal Problem Solving. Jurnal Konseling GUSJIGANG. Vol. 2 No. 1 (JanuariJuni 2016) 